\title{
PERBANDINGAN OHI-S ANTARA SISWA SD N 39 GUSUNG (DAERAH TEPENCIL) SEGERI KAB. PANGKEP DENGAN SISIWA SD NEG BADDOKA (DAERAH PERKOTAAN) KOTA MAKASSAR PADA KELAS IV DAN V
}

\author{
Badai Septa
}

\begin{abstract}
ABSTRAK
Mulut merupakan suatu tempat yang ideal untuk perkembangan bakteri karena temperature, kelembapan, dan sisa makanan, kebersihan gigi dan mulut ditentukan oleh sisa makanan (food debris), plak, kalkulus, pada permukaan gigi. Latar belakang penelitian yaitu membandingkan kebersihan gigi dan mulut seseorang yang dapat dilihat dengan tinggi rendahnya OHI-S (oral hygiene index simplified) merupakan perbandingan tentang kebersihan gigi dan mulut pada siswa SDN 39 Gusung dan SDN Baddoka penelitian ini bersifat Observasional yang dilakukan pemeriksaan langsung pada sampel dengan pemeriksaan OHI-S.Penelitian ini dilakukan dengan jumlah sampel 88 Orang terdiri dari 44 orang siswa SDN 39 Gusung dan 44 orang siswa SDN Baddoka. Dari hasil penelitan yang dilakukan diperoleh nilai rata-rata OHI-S pada siswa SDN 39 Gusung daerah terpencil yaitu 2,1dan termasuk dalam kategori Sedeng, sedangkan pada siswa SDN Baddoka daerah perkotaan yaitu 1,6 dan juga termasuk dalam kategori sedang. Kesimpulan dari penelitian ini, didapatkan perbedaan kebersihan gigi dan mulut antara siswa pedesaan dan perkotaan yang sangat signifikan.
\end{abstract}

Kata kunci : OHI-S, Plak, Kalkulus

\section{PENDAHULUAN}

Seseorang akan menginginkan kehidupan yang sehat dan terbatas dari berbagai penyakit. Sehat menuurut World Health Organization (WHO) mencakup sehat jasmani, rohani dan social ekonomi. Kesehatan gigi dan mulut merupakan bagian dari kesehatan jasmani yang tidak dapat dipisahkan satu dan lainnya karena akan memengaruhi tubuh secara keseluruhan. (Fara 2015)

Kesehatan gigi dan mulut sangatlah penting untuk menunjang kesehatan tubuh secara keseluruhan. Sebab mulut adalah pintu gerbang dari segala makanan dan minuman yang masuk kedalam tubuh tanpa kita sadari, kesehatan gigi dan mulut dapat berpengaruh secara signifikan terhadap organ- organ lain tubuh kita. ( Grace 2011)

Di Indonesia, penyakit gigi dan mulut terutama karies dan penyakit periodontal, masih banyak diderita, baik oleh anak-anak maupun usia dewasa. Sebagian besar masalah kesehatan gigi dan mulut sebenarnya dapat dicegah. Kesehatan mulut tidak sepenuhnya bergantung pada perilaku seseorang. Banyak cara untuk dapat mengurangi dan mencegah penyakit gigi dan mulut dengan berbagai pendekatan yang meliputi pencegahan yang dimulai dari masyarakat, perawatan oleh diri sendiri dan perawatan oleh tenaga professional. (Megananda, dkk 2010)

Pengetahuan tentang kesehatan gigi dan mulut sangat penting untuk terbentuknya tindakan dalam menjaga kebersihan gigi dan mulut. kesehatan gigi dan mulut untuk mencegah penyakit gigi dan mulut, meningkatkan daya tahan tubuh, dan memperbaiki fungsi mulut untuk meningkatkan nafsu makan. Menjaga kebersihan gigi dan mulut pada usia sekolah merupakan salah satu cara dalam meningkatkan kesehatan pada usia dini.(Yohanes,dkk 2013). 
Usia Sekolah Dasar merupakan saat yang sangat ideal untuk melatih kemampuan motorik seorang anak, termasuk diantaranya menyikat gigi, potensi menyikat secara baik dan benar merupakan factor yang cukup penting untuk pemeliharaan kesehatan gigi dan mulut.(Randi, 2015).

Kota Makassar merupakan ibu kota di Provinsi Sulawesi selatan yang merupakan koa metropolitan terbesar dikawasan Indonesia Timur. Makasar terletak dipesisir barat daya pulau Sulawesi dan berbatasan dengan selat Makassar disebelah barat, Kabupaten Kepulauan Pangkajene disebelah utara,Kabupaten Maros di sebelah Timur dan Kabupaten Gowa disebelah selatan. Luas wilayah 1999,26 km2 dan berjumlah penduduk lebih dari 1,6 juta jiwa. SDN Baddoka berada di jl Dg.Rmang kec Biringkanaya Kel.Pai Pangkep adalah salah satu kabupaten yang ada di provinsi Sulawesi Selatan, Indonesia. Ibu kotanya adalah Pangkajene. Kabupaten pangkep memiliki wilayah 1.112,29 km, tetapi setelah diadakan analisis bersama, luas wilayah tersebut direvisi menjadi 12,362,73 km, dengan luas wilayah daratan $898,29 \mathrm{~km}$. dan wilayah laut 11,4764,44km. SDN 39 Gusung berlokasi RT 8 Rw 2 di Gusung Kelurahan Bontomatene Kec segeri Kabupaten Pangkep. Berdasarkan data Observasi awal di SDN 39 gusung pada siswa kelas IV dan V berjumlah 44 orang dan SD NEG BADDOKA siswa kelas IV dan V berjumlah 44 orang. Sebagian besar belum bisa menerapkan kebiasaan menyikat gigi 2x sehari dan teknik menyikat gigi masih kurang baik. Berdasarkan latar belakang di atas peneliti tertarik untuk melaksanakan penelitian dengan judul perbandingan OHIS antara siswa SDN 39 GUSUNG (daerah terpencil) di Segeri Kab. Pangkep dengan SDN Baddoka (daerah perkotaan) kota Makassar pada Murid Kelas IV dan V.

\section{METODE PENELITIAN}

Penelitian ini merupakan penelitian deskriptif dengan pendekatan observasional untuk mengetahui perbandingan OHIS antara siswa SDN 39 Gusung dengan SDN Baddoka pada kelas IV dan V. Penelitian di SDN 39 GUSUNG dilaksanakan pada bulanApril- Mei 2017 sedangkan di SDN BADDOKA dilaksanakan pada bulan April- Mei 2017. Populasi dalam penelitian ini yaitu, Semua murid SDN 39 Gusung yang berjumlah 108 murid dan SDN Baddoka berjumlah 408 murid. Metode sampling yang digunakan yaitu Stratified Random Sampling, yaitu pengambilan sampel pada kelas IV dan V yang mewakili populasi. Sampel penilitian ini yaitu murid-murid SDN 39 Gusung pada kelas IV dan $V$ yaitu berjumlah 44 siswa dan SDN Baddoka pada kelas IV dan V berjumlah 44 siswa. Data disajikan dalam bentuk tabel. Data dikumpulkan, kemudian di tabulasi setelah itu, data di analisis dengan menggunakan SPSS Uji Indepentent Test.

\section{HASIL PENELITIAN}

Sampel penelitan adalah murid kelas IV dan V SD Negeri 39 Gusung dan murid kelas IV dan V Sekolah Dasar Negeri Baddoka yang berada pada kabupaten Pangkep dan kota Makassar. Jumlah sampel yang di periksa 
adalah 88 orang siswa yang terdiri dari 44 siswa SD Negeri 39 Gusung daerah terpencil pada Kabupaten Pangkep dan 44 siswa SD Negeri Baddoka daerah perkotaan kota
Makassar.setelah dilakukan pemeriksaan sampel,maka hasil yang diperoleh adalah sebagai berikut:

Tabel 1. Persentase Responden

\begin{tabular}{|c|c|c|}
\hline Nama Sekolah & Jumlah Responden & Persentase \\
\hline SD NEG 39 Gusung & 44 & $100 \%$ \\
\hline SD NEG Baddoka & 44 & $100 \%$ \\
\hline
\end{tabular}

Jumlah responden yang hadir pada saat pemeriksaan yaitu sebanyak 88 siswa yang terdiri dari 44 siswa dari SD Neg.39
Gusung daerah terpencil dan 44 siswa dari siswa SD Negeri Baddoka daerah perkotaan kota Makassar.

Tabel 2. Perbandingan Debris Index

\begin{tabular}{|r|c|c|c|c|}
\hline \multirow{2}{*}{ NAMA SEKOLAH } & \multicolumn{3}{|c|}{ Kriteria sampel } & \multirow{2}{*}{ RATA-RATA } \\
\cline { 2 - 4 } & Baik & Sedang & Buruk & \\
\hline SD NEG 39 GUSUNG & 2 & 42 & - & 2.1 \\
\hline SD NEG BADDOKa & 21 & 23 & - & 0.6 \\
\hline
\end{tabular}

Berdasarkan tabel 2, status Debris menunjukkan bahwa nilai rata-rata Debris pada siswa SD Neg 39 Gusung daerah terpencil Kab Pangkep yaitu 2.1 dan termasuk dalam kriteria buruk.dibandingkan dengan dengan nilai Ratarata debris pada siswa Sekolah Dasar Neg Baddoka daerah perkotaan Kota Makassar yaitu 0,6 dan termasuk dalam kriteriai Baik.

Tabel 3. Perbandingan Kalkulus Index

\begin{tabular}{|r|c|c|c|c|}
\hline \multirow{2}{*}{ NAMA SEKOLAH } & \multicolumn{3}{|c|}{ Criteria sampel } & \multirow{2}{*}{ RATA-RATA } \\
\cline { 2 - 4 } & Baik & Sedang & Buruk & \\
\hline SD NEG 39 GUSUNG & 15 & 21 & - & 0,3 \\
\hline SD NEG BADDOKA & 38 & 6 & - & 0,1 \\
\hline
\end{tabular}


Berdasarkan tabel 3, status KALKULUS INDEX menunjukkan bahwa nilai rata-rata Kalkulus pada siswa SD Neg 39 Gusung daerah terpencil kabupaten Pangkep yaitu 0,3 termasuk dalam criteria baik dan nilaii rata-rata Kalkulus Index pada siswa SD Neg Baddoka yaitu 0,1 daerah perkotaan kota Makassar yaitu termasuk dalam criteria baik.

Tabel 4. Perbandingan OHI-S

\begin{tabular}{|c|c|c|c|c|}
\hline \multirow{2}{*}{ NAMA SEKOLAH } & \multicolumn{3}{|c|}{ Criteria } & \multirow{2}{*}{ RATA-RATA } \\
\cline { 2 - 4 } & Baik & Sedang & Buruk & \\
\hline SD NEG 39 GUSUNG & 2 & 36 & 6 & 2.1 \\
\hline SD NEG BADDOKA & 17 & 27 & - & 1.6 \\
\hline
\end{tabular}

Berdasarkan tabel 4, status OHI-S menunjukkan bahwa nilai rata-rata $\mathrm{OHI}$-s pada siswa SD Neg 39 Gusung daerah terpencil kabupaten Pangkep yaitu 2.1 termasuk dalam

\section{PEMBAHASAN}

OHI-S merupakan suatu gambaran yang dilakukan untuk mengetahui tingkat kebersihan gigi dan mulut seseorang dengan menggunakan suatu criteria tertentu yang disebut dengan indeks. Indeks adalah suatu angka yang menunjukkan keadaaan klinis yang didapat pada waktu dilakukan pemeriksaan, dengan cara mengukur luar dari permukaan gigi yang ditutupi oleh plak maupun kalkulus, dengan demikian angka yg diperoleh berdasarkan penilain yang objektif. (sulistiyani dkk 2014).

Makanan dan minuman yang bersifat asam lama kelamaan juga dapat merusak gigi' . Berbeda dengan jenis makanan dan minuman yang lain. (Ramadhan 2010).

Hal ini karena sifatnya yang lunak, maka tidak perlu pengunyahan sehingga criteria Sedang dan nilaii rata-rata $\mathrm{OHI}-\mathrm{S}$ pada siswa SD Neg Baddoka yaitu 1.6 daerah perkotaan kota Makassar yaitu termasuk dalam kriteria sedang.

gampang melengket pada gigi bila tidak segera di bersihkan maka akan terjadi proses kimia bersama dengan bakteri dan air ludah yang dapat merusak lapisan email gigi. (Moestpo 1998)

Salah satu cara mudah untuk tetap menjaga kesehatan gigi yaitu mengatur pola makan dengan memperbanyak mengonsumsi makanan yang berserat seperti sayur dan buah-buahan. Makanan tersebut perlu dikunyah dengan lama sehingga gerkan menguyah dapat merangsang pengeluaran saliva (air liur) lebih banyak. Di dalam saliva terkandung Zat-zat seperti substansi antibakteri, senyawa kalsium dan flourida yang sangat berguna melindungi gigi. Mengunyah makanan berserat seperti buah-buahan dapat membantu membersihkan gigi. (Cahyati, 2013). 
Kebersihan mulut lebih efektif untuk mencegah penyakit gusi daripada gigi rusak. Makanan dipaksa di dalam pit dan fissura di bawah tekanan mengunyah, menyebabkan karbohidrat berbahan demineralisasi asam dimana disikat, pasta gigi fluoride, dan air liur tidak memiliki akses untuk melepas makanan yang terjebak, menetralisir asam, atau remineralisasi gigi demineralisasi yang lebih mudah diakses terhadap makanan gigi pada permukaan yang terjebak. Sera karet seperti seledri setelah memakan makanan di dalam air liur untuk mencairkan setiap karbohidrat seperti gula, menetralisir asam dan remineralisasi gigi demineralised. (Hongini 2012)

Berdasarkan hasil penelitian dari 88 sampel yang diperiksa, maka dapat dilihat pada table 1 jumlah responden, berasal dari 44 murid SD NEG 39 Gusung daerah terpencil kab Pangkep dan 44 murid berasal dari SD NEG Baddoka daerah perkotaan kota Makassar.

Pada table 2, terlihat nilai rata-rata Debris Index pada murid kelas IV dan V SD NEG 39 Gusung daerah terpencil Kabupaten Pangkep yaitu 2.1 termasuk dalam kategori sedang menurut criteria Debris Index,lebih rendah dari rata-rata nilai debris index rata-rata yang ditemukan pada siswa kelas IV Kebersihan mulut lebih efektif untuk mencegah penyakit gusi daripada gigi rusak. Makanan dipaksa di dalam pit dan fisura di bawah tekanan mengunyah, menyebabkan karbohidrat berbahan demineralisasi asam dimana disikat, pasta gigi fluoride, dan air liur tidak memiliki akses untuk melepas makanan yang terjebak, menetralisir asam, atau remineralisasi gigi demineralisasi yang lebih mudah diakses terhadap makanan gigi pada permukaan yang terjebak. Sera karet seperti seledri setelah memakan makanan di dalam air liur untuk mencairkan setiap karbohidrat seperti gula, menetralisir asam dan remineralisasi gigi demineralised. (Hongini 2012)

Berdasarkan hasil penelitian dari 88 sampel yang diperiksa, maka dapat dilihat pada tabel1 jumlah responden, berasal dari 44 murid SD NEG 39 Gusung daerah terpencil kab Pangkep dan 44 murid berasal dari SD NEG Baddoka daerah perkotaan kota Makassar.

Pada tabel 2, terlihat nilai rata-rata Debris Index pada murid kelas IV dan V SD NEG 39Gusung daerah terpencil Kabupaten Pangkep yaitu 2.1 termasuk dalam kategori sedang menurut kriteria Debris Index lebih rendah dari rata-rata nilai debris index rata-rata yang ditemukan pada siswa kelas IV Kebersihan mulut lebih efektif untuk mencegah penyakit gusi daripada gigi rusak. Makanan dipaksa di dalam pit dan fisura di bawah tekanan mengunyah, menyebabkan karbohidrat berbahan demineralisasi asam dimana disikat, pasta gigi fluoride, dan air liur tidak memiliki akses untuk melepas makanan yang terjebak, menetralisir asam, atau remineralisasi gigi demineralisasi yang lebih mudah diakses terhadap makanan gigi pada permukaan yang terjebak. Sera karet seperti seledri setelah memakan makanan di dalam air liur untuk mencairkan setiap karbohidrat seperti gula, menetralisir asam dan remineralisasi gigi demineralised. (Hongini 2012).

Berdasarkan hasil penelitian dari 88 sampel yang diperiksa, maka dapat dilihat pada table 1 jumlah responden, berasal dari 44 
murid SD NEG 39 Gusung daerah terpencil kab

Pangkep dan 44 murid berasal dari SD NEG

Baddoka daerah perkotaan kota Makassar.

Pada tabel 2, terlihat nilai rata-rata

Debris Index pada murid kelas IV dan V SD

NEG 39 Gusung daerah terpencil Kabupaten

Pangkep yaitu 2.1 termasuk dalam kategori sedang menurut criteria Debris Index,lebih rendah dari rata-rata nilai debris index rata-rata yang ditemukan pada siswa kelas IV dan V SD NEG Baddoka daerah perkotaan kota Makassar yaitu 0,6 termasuk dalam criteria baik.

Berdasarkan tabel 3, status Calkulus Index menunjukkan bahwa nilai rata-rata Kalkulus index kelas IV dan V siswa SD Neg 39 Gusung daerah terpencil kabupaten Pangkep yaitu 0,3 termasuk dalam criteria baik menurut criteria Kalkulus Index masih tinggi dibandingkan dengan nilaii rata-rata Kalkulus Index padakelas IV dan V siswa SD Neg Baddoka yaitu 0,1 daerah perkotaan kota Makassar yaitu termasuk dalam criteria baik.

Berdasarkan tabel 4, status OHI-S menunjukkan bahwa nilai rata- rata $\mathrm{OHI}-\mathrm{S}$ pada siswa SD Neg 39 Gusung daerah terpencil kabupaten Pangkep yaitu 1.6 termasuk dalam criteria Sedangmasih tinggi dibandingkan dengan nilaii rata-rata $\mathrm{OHI}-\mathrm{S}$ pada kelas IV dan V siswa SD Neg Baddoka yaitu 2.1 daerah perkotaan kota Makassar yaitu termasuk dalam criteria baik.

Masih tingginya tingkat $\mathrm{OHI}-\mathrm{S}$ yang ditemukan pada siswa Sekolah Dasar Negeri 39 Gusung yang berada pada daerah terpencil Kab Pangkep, disebabkan oleh karena tingkat pengetahuan mengenai tentang menjaga kebrsihan gigi dan mulut, jarak sekolah dari puskesmas segeri cukup jauh maka program UKGS tidak ada. Sehingga pengetahuan tentang kesehatan gigi dan mulut sangat rendah, teknik menyikat gigi dan frekuensi menyikat gigi setiap hari masih sangat rendah.

Factor lain yang dapat menyebabkan gigi dan mulut anak adalah kurangnya perhatian dan pengetahuan orang tua dan guru dalam memlihara kesehatan gig dan mulut sejak dini, dan pola makan yang tidak sesuai. Oleh karena itu dibandingkan dengan Oral Hygiene yang ditemukan pada siswa SD NEG Baddoka dapat dilihat dengan jelas bahwa program UKS dan UKGS yang dilaksanakan puskesmas Sudiang raya cukup berjalan dengan baik, dan perlu peningkatan untuk mendapatkan kesehatan gigi dan mulut yang maksimal.

Rendahnya penilaian Oral Hygiene yang ditemukan pada siswa SD NEG Baddoka yang terletak pada daerah perkotaan kota Makassar yaitu pengetahuan tentang kesehatan gigi dan mulutyang didapatkan oleh orang tuan dan pengetahuan guru disekolah sudah sangat baik ditambah dengan frekuensi dan teknik menyikat gigi yang sudah sangat baik karena pengetahuan dan guru sudah diajarkan sejak dini kepada anak siswa mereka untuk mencapai derajat kesehatan yang lebih baik.

\section{KESIMPULAN}

Status indeks kebersihan gigi dan mulut pada siswa Daerah terpencil masih sangat rendah yang disebabkan oleh pengetahuan siswa pentingnya merawat 
kesehatan gigi dan mulut masih kurang, pengetahuan orang tua mengenai kesehatan gigi dan mulut masih rendah, letak geografis,Unit Kesehatan gigi dan mulut sekolah belum ada, serta penyuluhan tentang kesehatan gigi dan mulut belum pernah diberikan, ini berarti tingkat kebersihan gigi dan mlut masih rendah dibandingkan dengan siswa sekolah Dasar daerah perkotaan yang memiliki tingkat kebersihan gigi dan mulut yang cukup baik berpengaruh dengan kebiasaan menyikat gigi dengan teratur serta Teknik menyikat gigi yang baik dan benar.

\section{SARAN}

Untuk memperbaiki status kesehatan gigi dan mulut para siswa sekolah dasar diharapkan bantuan dari beberapa pihak tenaga kesehatan untuk lebih meningkatkan memberikan pengetahuan kesehatan gigi dan mulut pada terutama pada daerah terpencil.

\section{DAFTAR PUSTAKA}

Djamil.M.S, MBiomed 2011. A-Z Kesehatan gigi.(panduan Lengkap kesehatan gigi keluarga).solo.Metagraf.

Gopdianto.R.Rattu.J.A.M.Status Kebersihan Gigi dan Perilaku Menyikat Gigi AnakSD Neg 1 Malalayang.Yogyakarta.Jurnal e-Gigi (eG), Volume,3,Nomor 1,130,JanuariJuni 2015.130-`138.

Hongini.S.T. Aditiawarman.2012. Kesehatan Gigi dan Mulut.pustaka. BandungJawa Barat. pustaka reka cipta.

Irma I. Intan A.S. Penyakit Gigi, Mulut, dan THT.Yogyakarta 2013. Medicalbook. k.k.I gede.Y.Pandelaki Karel. Mariati W.Ni. Hubungan pengetahuan Kebersihan gigi dan mulut dengan status kebersihan gigi dan mulut pada siswa SMA Negeri 9.Manado. Jurnal e-gigi (eg),volume 1, Nomor 2, Sepetember 2013.hal 84-88

Lossu.M.fara.Pengemanan.H.C.Dama.Wowor. N.S.Vonny.Hubungan pengetahuan Kesehatan Gigi dan mulut dengan indeks gingival siswa SD Katolik 3 Frater Don Bosco.Manado. Jurnal.e gigi (eg), volume 3.,nomor 2,JuliDesember2015.

Machfoeds I. Zein.A.Y. Menjaga Kesehatan gigi dan mulut anak dan ibu hamil. Yogyakarta.Fitramaya 2008.

Mitchel L.Mitchel D.A.Mc

Caul.Lorna.2014.Kedokteran Gigi klinik Semua bidang Kedokteran gigi. EGC.Jakarta. 2014

Mumpuni.Y.Pratiwi E.45 Masalah dan Solusi penyakit Gigi dan Mulut.Yogyakarta.Rapha Publishing. 2013.

Oktaviani.W.Dpurbasari N.2014.Perbandingan OHI-'S DMT-'T dan def-'t pada sisiwa sekolah dasar berdasarkn letak Geografis. Situbondo.e-Jurnal Pustaka

Kesehatan,Vol.2(no.1)Januari 2014.34.

Pratiwi.Donna. 2007.Gigi Sehat Merawat gigi sehari-hari.jakarta. Kompas. Maret 2007.28.

Putri.H.M.Herijulianti.E.Nurjannah.N.2010. IImu Pencegahan Penyakit Jaringan Keras dan Jaringan pendukung gigi.cetakan 2013. Buku kedokteran EGC.

Putri.H.M.Herijulianti.E.Nurjannah.N.2010. Ilmu Pencegahan Penyakit Jaringan Keras dan Jaringan pendukung gigi.cetakan 2013. Buku kedokteran EGC.

Sumini,Amikasi.B,Nurhayati.D. Hubungan konsumsi Makanan MAnis dengan Kejadian Karies Gigi pada Anak Prasekolah di TK B RA Muslimat PSM Tegalrejodesa semen Kecamatan Nguntoronadi Kabupaten Magetan.Jurnal Delima Harapan, Vol 3, No.2 Agustus-Januari 2014.20- 27.

Susanto.W.Grace.2011.Terapi Gusi untuk Kesehatan dan Kecantikan. Semarang. Erlangga2011. 